\title{
Destination Atmosphere and Destination Branding: As an Effort to Promote Tourism in Banten
}

\author{
Liza Mumtazah Damarwulan \\ Faculty of Economics and Business, Universitas Sultan Ageng Tirtayasa, Indonesia \\ damarwulanliza@gmail.com
}

\section{Abstract}

This study departs from the problem that there are still many tourist attractions or tourist destinations in Indonesia that have not been exposed and need a touch of promotion in order to encourage the level of tourist visits. One of them is by using destination branding and destination atmosphere as an effort to attract the interest of visiting the community and in the end the community can make a decision to visit the destination tourist location. This study aims to further examine the destination branding and destination atmosphere as an effort to promote tourism in Banten. This type of research is quantitative research. The data collection technique in this study was conducted by survey techniques using a questionnaire as a research instrument, with a purposive sampling technique. Data analysis used (SEM) analysis techniques and AMOS program analysis tools. The results show that there is a positive and significant influence between social media and visiting interest, destination branding has a positive and significant effect between visiting interest, destination atmosphere has a positive and significant effect between $g$ and visiting interest, there is a positive and significant influence between destinations. Branding with visiting decisions, there is no positive and significant influence between destination atmosphere and visiting decisions, and there is a positive and significant influence between interest in visiting and visiting decisions.
Keywords

destination branding, destination atmosphere; tourism

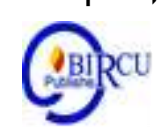

\section{Introduction}

In Indonesia, there are many places that can be used as tourist destinations. Starting from historical places such as temples and relics of ancient times, places to enjoy its natural beauty, from sea tours, hills, mountains, lakes, religious tourism, and also places that can add insight while on vacation such as museums and other educational vehicles.

According to Law No.10 / 2009 on tourism, what is meant by tourism is various kinds of tourism activities and is supported by various facilities and services provided by the community, businessmen, government and local governments. The tourism sector is one of the important sectors in terms of foreign exchange earnings. It was recorded that in 2014 and 2015, tourism succeeded in ranking fourth in terms of foreign exchange earnings after oil and gas, coal and palm oil (http://www.kemenpar.go.id/). In 2016, there were more than 11 million foreign tourists who came to Indonesia, an increase of $10.69 \%$ compared to the previous year which reached more than 10 million people (http://www.kemenpar.go.id/). 
There are still many tourist attractions or tourist destinations in Indonesia that have not been exposed and need a touch of promotion in order to encourage the level of tourist visits. One of them is by using destination branding as an effort to attract the interest of visiting the community and in the end the community can make a decision to visit the destination tourist location.

Situmorang (2018) states that 'Brand' is a very important differentiating factor in a sea of similar products / services. Brands have a special psychological and symbolic meaning in the eyes of tourists or tourists. In other words, if the branding of a tourist spot has been formed, it will become a very valuable asset for that tourist spot because it is not owned by other tourist attractions. This can also be a separate source of income for these tourist attractions, because it can influence the interests and decisions of tourists to visit.

An example of an area that has done destination branding is Solo City with its branding slogan "Solo, Soul of Java", and there are many other tourist attractions that have declared their regional image. In addition to destination branding, efforts that need to be made by the government and tourism management companies are to provide a good atmosphere in the tourist area.

Destination atmosphere in tourist attractions really needs to be considered to attract tourists to visit. Because now the atmosphere of a tourist spot can influence visitor interest and can be a reason for visitors to choose a place to tour (Kotler, P. et al., 1999). In fact, not a few visitors prefer to visit a tourist spot on the grounds of liking the atmosphere at the place concerned. And visitors tend to spend more money than planned due to the attractive atmosphere (Berman, 1997).

Baker et al. (1994) also added that by showing a tourist spot that has a good and elegant atmosphere, the tourist spot can give a good social impression in the eyes of visitors. And if this positive impression lasts for a long time, then the tourist spot will influence the interest of tourists to visit again and become the main choice for these tourists to enjoy the tours offered. According to (Barry \& Evans, 1997), "Atmosphere can be divided into several elements: exterior, general interior, store layout, and displays."

One of the places in Indonesia that has many tourist attractions is Pandeglang Regency. This regency, which is located in Banten Province, does have many places that can be used as tourist destinations. Natural attractions such as beaches, mountains, animal breeding parks, swimming pools, hot spring pools etc. However, there are still many potential tourist attractions in Pandeglang Regency that have not been maximally exposed. The government and the manager of tourist attractions have not been optimal in attracting interest and decisions from tourists to visit, it can be seen from the number of visitors. The atmosphere offered by the Regional Government of Pandeglang is still not optimal, it can be seen from the outside and inside the tourist spot.

This makes researchers more interested in testing and offering strategies through destination branding as well as suggesting the importance of the atmosphere in a tourism industry. In addition to the tourism conditions in Pandeglang Regency, this research was also conducted based on several different research results in the results of testing the relationship between destination branding and interest and visiting decisions.

Here are some studies related to atmosphere and branding. Meldarianda et al., (2010) conducted research on the Resort Café Atmosphere, and found that the instore atmosphere in that place had a positive influence on buying interest or visiting interest. Likewise, research conducted by Hakim \& Hidayat (2017) states that brand image has a significant influence on purchase intention. 
Based on the identification of the research, the purpose of this study is to identify and analyze the factors that influence the interest in visiting the community at tourist attractions in Pandeglang district.

\section{Review of Literatures}

\subsection{Social Media}

In this digital era, promotional trends have developed by utilizing technology. Specifically, this trend has now led to the use of social media as a promotional medium. Promotion through social media is considered quite effective because it does not require large costs and has a wider reach than conventional promotions, so it can reach domestic and foreign markets in a short time (Todua, 2017; Ukpabi \& Karjaluoto, 2017). Through social media, companies can also embrace various market segments because the age range of social media users is not only limited to teenagers, so the market segment becomes more dynamic.

Social media marketing (marketing through social media) is a form of marketing strategy by utilizing social media in an effort to market a product / brand and service to communities that participate in social media (Lim et al., 2012; Minazzi, 2015). Social media marketing activities are basically an effort to create content in the form of posts, writings, images, and videos that attract attention and encourage the community to interact and share this content through their social networks.

\subsection{Destination Branding}

Destination branding is a series of marketing activities that include the creation of names, symbols, logos, signs, words or other graphics that easily identify and distinguish a destination from other goals. Destination branding must also be in accordance with the expectations of visitors and create a unique, unforgettable experience, moreover, it can serve to strengthen the relationship between visitors and tourist attractions.

Broadly speaking, this activity serves to create a positive image of a tourist spot so that it can influence visiting decisions (Blain et al., 2005). Similar to common knowledge about brands, destination branding uses two important functions, namely identification and differentiation. In some branding literature, the meaning of "identification" involves describing the source of the product to the consumer. Whereas the product in general is the physical form that is offered, which can be easily modified. In destination branding, a tourist spot is the product offered, where the place has something unique to explain the identity of the place (Florek, 2005).

\subsection{Destination Atmosphere}

Atmosphere is a planned atmosphere in accordance with the target market and which can attract consumers to buy or visit. The atmosphere can be captured through the five basic human senses, namely sight, sound, smell, touch, and taste (Kotler, 2005). According to Levy \& Weitz (2001), Store atmosphere consists of two things, namely Instore atmosphere and Outstore atmosphere; this can be used as an indicator of the destination atmosphere.

Instore atmosphere is an indoor setting that concerns:

1. Internal Layout which is an arrangement of various indoor facilities consisting of the table layout and chairs for visitors, the layout for the cashier table, and the layout for lighting, air conditioning, sound. 
2. Sound which is the whole sound that is presented in the room to create a relaxed impression consisting of live music served by the restaurant and music from the sound system.

3. Odors are aromas that are presented in the room to create an appetite that arises from the aroma of food and smells and aromas caused by room deodorizers.

4. Texture which is the physical appearance of the materials used for tables and chairs in the room and the walls of the room.

5. The interior design of the building which is the arrangement of the spaces in the restaurant. The suitability includes the suitability of the area of the visitor's room with the road that provides comfort, bar counter design, table arrangement, arrangement of paintings, and indoor lighting system.

While Outstore atmosphere is an outdoor setting that concerns:

1. External Layout, which is the arrangement of the layout of various outdoor facilities which includes the visitor parking layout, nameplate layout, and strategic locations.

2. Texture, which is the physical appearance of the materials used in buildings and outdoor facilities, which includes the texture of the walls of the outdoor buildings and the texture of the outdoor signage.

3. Building exterior design, which is the arrangement of the rooms outside the restaurant, includes the design of the outdoor signage, the placement of the entrance, the shape of the building as seen from the outside, and the outdoor lighting system.

\subsection{Visiting Intention}

Sutisna dan Pawitra \& Pawitra (2001) say that buying interest is something that is related to the consumer's plan to buy a certain product and how many units of the product are needed in a certain period. He further said that purchase intention is a consumer's selfinstruction to make a purchase for a product, plan, take relevant actions such as proposing, recommending, selecting, and finally deciding to make a purchase.

Based on this understanding, the interest in visiting is an encouragement to visit the intended tourist spot, with the process of planning, proposing, recommending, selecting, and finally making decisions to visit tourist destinations.

\subsection{Visiting Decision}

The definition of a visiting decision refers to the definition of a purchasing decision stated by (Kotler \& Armstrong, 2010) that a buying / visiting decision is a buyer / visitor's decision about what brand / destination to buy / visit. The purchase decision / visiting decision stage is carried out when consumers evaluate alternatives that form preferences for brands in the selection set. In carrying out the purchase intention, consumers can make five sub-decisions including: brand, dealer, quantity, time, and method of payment.

\subsection{Preliminary Study and Results Achieved}

Previous research on consumer buying interest can be seen in the research conducted by (Sugiarto, 2014) entitled "Analysis of the Effect of Product, Service Quality, Price, and Store Atmosphere on Purchase Intention at Dream Of Khayangan Art Resto Surabaya". The variables studied were product quality, service quality, price, atmosphere, and purchase intention. This study found that all dependent variables have a positive influence on purchase intention.

Research conducted by (Meldarianda et al., 2010) entitled "The Influence of Store Atmosphere on Consumer Purchase Intention at Resort Café Atmosphere Bandung". The variables studied were atmosphere and purchase interest using multiple linear regression 
analysis. This study found that there is an influence between the store atmosphere which consists of instore and outstore atmosphere on consumer buying interest.

Research conducted by (Hakim \& Hidayat, 2017) entitled "The Influence of Brand Image on Consumer Purchase Intention at Bimbel Tridaya Bandung". The variables examined in this study were brand image and purchase interest using simple linear regression analysis techniques. This study shows the results that the brand variable has an influence on consumer interest.

Research conducted by (Erdil, 2015) entitled "Effects Of Customer Brand Perceptions On Store Image And Purchase Intention: An Application In Apparel Clothing". The variables examined in this study were brand image, price image, and purchase interest using multiple linear regression analysis. This study shows the results that brand image and price image have a direct influence on consumer interest.

Research conducted by (Putri, 2014) entitled "The Influence of Store Atmosphere on Purchasing Decisions and Customer Satisfaction (Studies on Monopoly Cafe And Resto Soekarno Hatta Malang)". The variables studied are store atmosphere, purchasing decisions, and customer satisfaction. This type of research is explanatory research which is used to test a theory or hypothesis. The results showed that the atmosphere had a significant effect on purchasing decisions, but did not have a significant effect on customer satisfaction, and purchasing decisions had a significant effect on customer satisfaction.

Research conducted by (Ong, 2013) entitled "Analysis of the Influence of Differentiation Strategies, Brand Image, Product Quality and Prices on Customer Purchasing Decisions at Cincau Station Surabaya". The variables examined in this study are differentiation strategies, brand image, product quality, price and purchase decisions, using the SPSS test tool. This study shows the results that all independent variables, including brand, have a significant influence on purchasing decisions.

Based on previous studies, there are differences between the results of one study and another; and this is the main attraction for researchers to answer the research gap. From the differences in the results of these studies, this study was conducted, to look for factors that could influence visiting interest behavior.

It is hoped that with this research, through literature review and systematic testing of the formulated model, this research will be able to prove the factors that influence the behavior of tourists' visiting interest. This study is also expected to answer the differences in research results (research gaps) between destination branding and destination atmosphere on interest in visiting.

\section{Research Methods}

This research was conducted in Pandeglang Regency. The research object is the visitor of tourist attractions in Pandeglang Regency. This type of research is a quantitative study, the results of which are then described from the results of distributed questionnaires. The data collection technique in this study was carried out by survey techniques using a questionnaire as a research instrument and supported by literature study. The sampling technique was done randomly, purposive sampling. Data analysis is quantitative or statistical in nature with the aim of testing predetermined hypotheses. The data analysis in this research is quantitative data analysis. Initial data were screened and trimmed, then tested for validity and reliability, face validity tests, and revised questionnaires. After the data is fixed, it is analyzed using the Structural Equation Modeling (SEM) analysis technique and the AMOS (Analysis of Moment Structure) program analysis tool. Data processing software used is IBM SPSS statistics for windows version 20. 


\section{Results and Discussion}

Based on the results of this research data processing with 100 respondents who were given a questionnaire who had visited tourist attractions in Pandeglang, the following results were obtained:

a. Validity Test

The correlation of each of these factors is positive and $>0.3$ with a significant level of $\leq 0.05$, it is declared valid. Of all the existing variables, namely destination branding (X1), destination atmosphere (X2), interest in visiting (Z), and visiting decisions (Y) have a positive correlation value.

b. Reliability Test

From the results of data processing, the Cronbach alpha value resulted in a value of more than 0.70; So that it can be stated that the measuring instruments for destination branding, destination atmosphere, interest in visiting and visiting decisions are reliable based on interval limits on the measurement of reliability.

c. Normality test

The statistical value of the Kolmogorov Smirnov $\mathrm{Z}$ test shows the Asymp value. Sig (2-tailed)> 0.05; so, it can be seen that the dependent variable is normally distributed and it can be stated that the data is normally distributed.

d. Multicollinearity Test

Obtained from the sample that there is no multicollinearity, because the statistical magnitude of tolerance is quite high (> 0.10) and the VIF (Variance Inflaction Factor) value for VIF $<10.00$.

e. Heteroscedasticity Test

Obtained the value of Sig> 0.05; these results indicate that heteroscedasticity does not occur.

f. Linearity Test

Obtained a significance value greater than 0.05 ; these results indicate that the variables have a significant linear relationship.

\subsection{Hypothesis Testing Results}

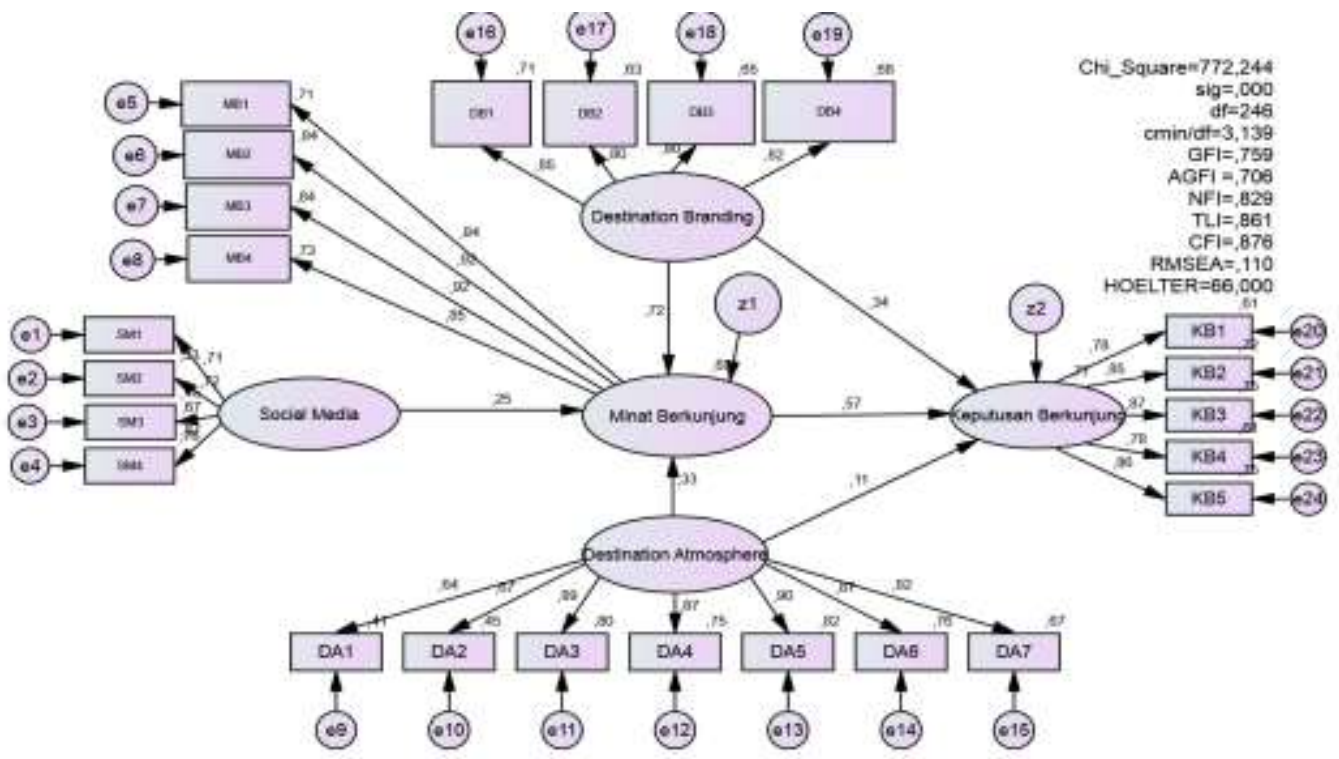

Figure 1. Hypothesis Testing Results 
Table 1. Regression Weights: (Group number 1 - Default model)

\begin{tabular}{|ll|lllll|}
\hline & & & Estimate & S.E. C.R. & P & Label \\
\hline MB & $<---~ S M$ &, 241 &, 082 & 2,944 &, 003 & par_18 \\
MB & <--- DB &, 534 &, 074 & 7,192 & $* * *$ & par_20 \\
MB & <--- DA &, 263 &, 066 & 3,989 & $* * *$ & par_21 \\
KB & <--- MB &, 581 &, 100 & 5,834 & $* * *$ & par_19 \\
KB & <--- DB &, 257 &, 088 & 2,912 &, 004 & par_22 \\
KB & <--- DA &, 087 &, 061 & 1,432 &, 152 & par_23 \\
\hline
\end{tabular}

\subsection{Discussion}

1. There is a significant positive influence between social media variables on 'interest in visiting'. This explains that social media has an impact on interest in visiting Cisolong hot springs.

2. There is a significant positive influence between destination branding variables on visiting interest. This explains that a good assessment and in accordance with the wishes of visitors regarding destination branding will attract the attention of visitors so that visitors are interested in visiting Cisolong hot springs. This result is in accordance with the research conducted by (Putra \& Bimo, 2015) which shows that the company image has a significant positive effect on visiting interest.

3. There is a significant positive influence between the destination atmosphere variable on visiting interest. This explains that an attractive and comfortable destination atmosphere can make visitors interested in visiting Cisolong hot springs. These results are consistent with research conducted by (Julianti et al., 2014) which states that store atmosphere has a positive and significant effect on consumer purchase interest.

4. There is a significant positive influence between destination branding variables on visiting decisions. Strong and unique destination branding can improve tourists' visiting decisions (Qu et al., 2011).

5. There is no influence between destination atmosphere on visiting decisions. This explains that the destination atmosphere has not played an important role in attracting visitors and making visitors comfortable, so that visitors will recommend to others, and visitors will revisit. These results are not in line with research conducted by (Putri, 2014) which shows that the atmosphere has a positive and significant influence on purchasing decisions.

6. There is a significant positive influence between the variable interest in visiting the decision to visit. This shows that after visitors pay attention and then find out positive information, visitors will focus on visiting Cisolong hot springs. These results are in accordance with research conducted by (Widyanto et al., 2017) which states that the visiting interest variable has a positive and significant effect on visiting decisions.

\section{Conclusion}

Based on the results of the research and discussion that has been presented in the previous chapters, the following conclusions can be drawn:

1. There is a positive and significant influence between social media and interest in visiting.

2. There is a positive and significant influence between destination branding and interest in visiting. 
3. There is a positive and significant influence between the destination atmosphere and the interest in visiting.

4. There is a positive and significant influence between destination branding and visiting decisions.

5. There is no positive and significant influence between the destination atmosphere and the decision to visit.

6. There is a positive and significant influence between interest in visiting and visiting decisions.

\section{Suggestions}

1. Based on the research results, the weakest indicator of destination branding in Cisolong hot springs is a presented brand which is not considered attractive enough. Although Cisolong hot springs have a destination branding that is easy to remember, the destination branding of Cisolong hot springs is not attractive enough. In order to make the destination branding in the Cisolong hot spring look more attractive, researchers suggest that the Cisolong hot spring baths make destination branding in the form of a logo, image, or symbol that describes the situation and condition as well as the characteristics of the tourist spot. In addition to being more attractive, using an image or logo for a tourist spot will make the tourist spot easier for tourists to recognize and remember.

2. Based on the results of the study, the weakest indicator of the destination atmosphere is located on the outside of the tourist attractions or outstore atmosphere, which is the nameplate that belongs to the Cisolong hot spring bath. Apart from the rusty nameplate, the shape of the nameplate and writing style are still not attractive. Researchers suggest that the nameplate in Cisolong hot spring be made more attractive, by using a different font than before; as well as the use of materials, shapes, and sizes of the nameplate, can be made more varied.

\section{References}

Baker, J., Grewal, D., \& Parasuraman, A. (1994). The influence of store environment on quality inferences and store image. Journal of the Academy of Marketing Science, 22(4), 328-339.

Barry, B., \& Evans, J. (1997). Marketing, Seventh edition, New Jersey:Prentice Hall. Inc.

Berman, E. M. (1997). Dealing with cynical citizens. Public Administration Review, 105112.

Blain, C., Levy, S. E., \& Ritchie, J. R. B. (2005). Destination branding: Insights and practices from destination management organizations. Journal of Travel Research, 43(4), 328-338.

Erdil, T. S. (2015). Effects of customer brand perceptions on store image and purchase intention: An application in apparel clothing. Procedia-Social and Behavioral Sciences, 207, 196-205.

Florek, M. (2005). The country brand as a new challenge for Poland. Place Branding, 1(2), $205-214$.

Hakim, A. R., \& Hidayat, R. (2017). Pengaruh Brand Image Terhadap Minat Beli Konsumen (Studi Pada Bimbingan Belajar Tridaya Bandung 2017). EProceedings of Applied Science, 3(2). 
Julianti, N. L., Nuridja, I. M., \& Meitriana, M. A. (2014). Pengaruh Suasana Toko (Store Atmosphere) Terhadap Minat Beli Konsumen Pada Toserba Nusa Permai di Kecamatan Nusa Penida Tahun 2014. Jurnal Pendidikan Ekonomi Undiksha, 4(1).

Kotler, P., Bowen, J., \& Makens, J. (1999). Marketing for hospitality and tourism (2nd ed) Upper Saddle River: Prentice Hall Intl., Inc.

Kotler, P. (2005). Manajemen Pemasaran Edisi 11 Jilid 1 dan 2, PT. Indeks.

Kotler, P., \& Armstrong, G. (2010). Principles of Marketing, thirteen edition. New Jersey, NJ: Pearson Prentice Hall.

Levy, M., \& Weitz, B. A. (2001). Retailing Management, Fourth edition, Richard D. Irwin Inc.

Lim, Y., Chung, Y., \& Weaver, P. A. (2012). The impact of social media on destination branding: Consumer-generated videos versus destination marketer-generated videos. Journal of Vacation Marketing, 18(3), 197-206.

Meldarianda, R., Lisan, H., \& Kristen, U. (2010). Pengaruh store atmosphere terhadap minat beli konsumen pada resort café atmosphere Bandung. Jurnal Bisnis Dan Ekonomi (JBE), 17(2), 97-108.

Minazzi, R. (2015). Social_Media_Marketing in Tourism and Hospitality.

Ong, I. A. (2013). Analisa pengaruh strategi diferensiasi, citra merek, kualitas produk dan harga terhadap keputusan pembelian pelanggan di Cincao Station Grand City, Surabaya. Jurnal Strategi Pemasaran, 1(2), 1-11.

Putra, S., \& Bimo, G. (2015). Pengaruh citra perusahaan terhadap minat berkunjung dan Keputusan Berkunjung (Survei Pada Pengunjung Taman Rekreasi PT. Selecta, Kota Batu, Jawa Timur). Jurnal Administrasi Bisnis, 26(2).

Putri, L. H. (2014). Pengaruh store atmosphere terhadap keputusan pembelian dan kepuasan pelanggan (Studi pada monopoli Cafe and Resto Soekarno Hatta Malang). Jurnal Administrasi Bisnis, 15(2).

Qu, H., Kim, L. H., \& Im, H. H. (2011). A model of destination branding: Integrating the concepts of the branding and destination image. Tourism Management, 32(3), 465476.

Situmorang, S. H. (2018). Destination brand: membangun keunggulan bersaing daerah. Wahana Hijau Jurnal Perencanaan \& Pengembangan Wilayah, 4(2), 84.

Sugiarto, B. U. (2014). Analisa Pengaruh Produk, Kualitas Pelayanan, Harga, Dan Store Atmosphere Terhadap Minat Beli Di Dream Of Khayangan Art Resto Surabaya. Jurnal Strategi Pemasaran, 2(1), 1-14.

Sutisna dan Pawitra, \& Pawitra. (2001). Perilaku Konsumen dan Komunikasi Pemasaran, Bandung. Penerbit PT. Rosdakarya.

Todua, N. (2017). Social media marketing for promoting tourism industry in Georgia.

Ukpabi, D., \& Karjaluoto, H. (2017). Influence of social media on corporate heritage tourism brand. In Information and Communication Technologies in Tourism 2017 (pp. 697-709). Springer.

Widyanto, A., Sunarti, S., \& Pangestuti, E. (2017). Pengaruh E-WOM di Instagram terhadap Minat Berkunjung dan Dampaknya pada Keputusan Berkunjung (Survei pada Pengunjung Hawai Waterpark Malang). Jurnal Administrasi Bisnis, 45(1), 94101. 